\title{
Matchout deuterium labelling of proteins for small-angle neutron scattering studies using prokaryotic and eukaryotic expression systems and high cell-density cultures
}

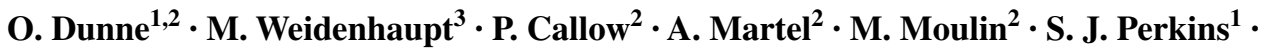 \\ M. Haertlein ${ }^{2}$ V. T. Forsyth ${ }^{2,4}$
}

Received: 7 January 2016 / Revised: 19 October 2016 / Accepted: 28 October 2016 / Published online: 14 November 2016 (C) The Author(s) 2016. This article is published with open access at Springerlink.com

\begin{abstract}
Small-angle neutron scattering (SANS) is a powerful technique for the characterisation of macromolecular structures and interactions. Its main advantage over other solution state approaches is the ability to use $\mathrm{D}_{2} \mathrm{O} / \mathrm{H}_{2} \mathrm{O}$ solvent contrast variation to selectively match out specific parts of a multi-component system. While proteins, nucleic acids, and lipids are readily distinguished in this way, it is not possible to locate different parts of a protein-protein system without the introduction of additional contrast by selective deuteration. Here, we describe new methods by which 'matchout labelled' proteins can be produced using Escherichia coli and Pichia pastoris expression systems in high cell-density cultures. The method is designed to produce protein that has a scattering length density that is very close to that of $100 \% \mathrm{D}_{2} \mathrm{O}$, providing clear contrast when used with hydrogenated partner proteins in a complex. This allows the production of a single sample system for which SANS measurements at different solvent contrasts can be used to distinguish and model the hydrogenated component, the deuterated component, and the whole complex. The approach, which has significant cost advantages, has been extensively tested for both types of expression system.
\end{abstract}

V. T. Forsyth

tforsyth@ill.eu

1 Department of Structural and Molecular Biology, University College London, Gower Street, London WC1E 6BT, UK

2 Institut Laue Langevin, 71 avenue des Martyrs, 38042 Grenoble Cedex 9, France

3 University Grenoble Alpes, CNRS, LMGP, F-38000 Grenoble, France

4 Macromolecular Structure Group, Faculty of Natural Sciences, Keele University, Staffordshire ST5 5BG, UK
Keywords Matchout deuteration - Contrast variation · SANS $\cdot$ Neutron scattering

\section{Introduction}

Small angle neutron scattering (SANS) and small-angle X-ray scattering (SAXS) provide important low resolution structural information on biological macromolecules in solution (Jacrot 1976; Glatter and Kratky 1982; Serdyuk et al. 2007). SANS approaches have the unique advantage of being able to exploit solvent contrast variation through the use of buffers containing specific $\mathrm{D}_{2} \mathrm{O} / \mathrm{H}_{2} \mathrm{O}$ ratios (Stuhrmann 1974; Svergun et al. 2013). This capability arises from the different neutron scattering properties of hydrogen $\left({ }^{1} \mathrm{H}\right.$, neutron coherent scattering length $\left.b_{\mathrm{c}}=-3.7423 \mathrm{fm}\right)$ and its heavy isotope deuterium $\left({ }^{2} \mathrm{H}\right.$ or $\mathrm{D}$, neutron coherent scattering length $b_{\mathrm{c}}=6.675 \mathrm{fm}$ ) (Shull 1962). This results in the very different scattering length densities (SLDs) of $-0.562 \times 10^{10} \mathrm{~cm}^{-2}$ and $6.404 \times 10^{10} \mathrm{~cm}^{-2}$ for $\mathrm{H}_{2} \mathrm{O}$ and $\mathrm{D}_{2} \mathrm{O}$, respectively. When specific $\mathrm{H}_{2} \mathrm{O} / \mathrm{D}_{2} \mathrm{O}$ solvent mixtures are made, it is therefore possible to make solutions having any SLD in this range (Fig. 1, black line). In the normal (hydrogenated) context, the major classes of biomolecules (protein, lipid, nucleic acid) exhibit naturally occurring differences in SLD. By changing the SLD of the solvent (buffer) to match specific parts of the biomolecule being studied, each part of the complex can be individually 'matched out' and rendered invisible to SANS data collection (Jacrot 1976). Figure 1 shows the variation of SLD as a function of $\mathrm{D}_{2} \mathrm{O} / \mathrm{H}_{2} \mathrm{O}$ composition by volume for the different classes of biomolecules, including deuterated proteins. Hydrogenated protein shows a match point at approximately $40 \% \mathrm{D}_{2} \mathrm{O}$, while nucleic acids show a match point of $\sim 62 \%$. This means, for example, that SANS data 
recorded for a protein-DNA complex in $40 \% \mathrm{D}_{2} \mathrm{O}$ buffer will reveal only the DNA structure. Likewise, SANS data measured using $\sim 62 \% \mathrm{D}_{2} \mathrm{O}$ when the DNA is matched out will reveal the protein component alone (Fig. 1). This powerful approach enables different parts of the same complex to be modelled both separately and together (Callow et al. 2007; Niemann et al. 2008; Obarska-Kosinska et al. 2008; Rochel et al. 2011; Vijayakrishnan et al. 2011; Taylor et al.

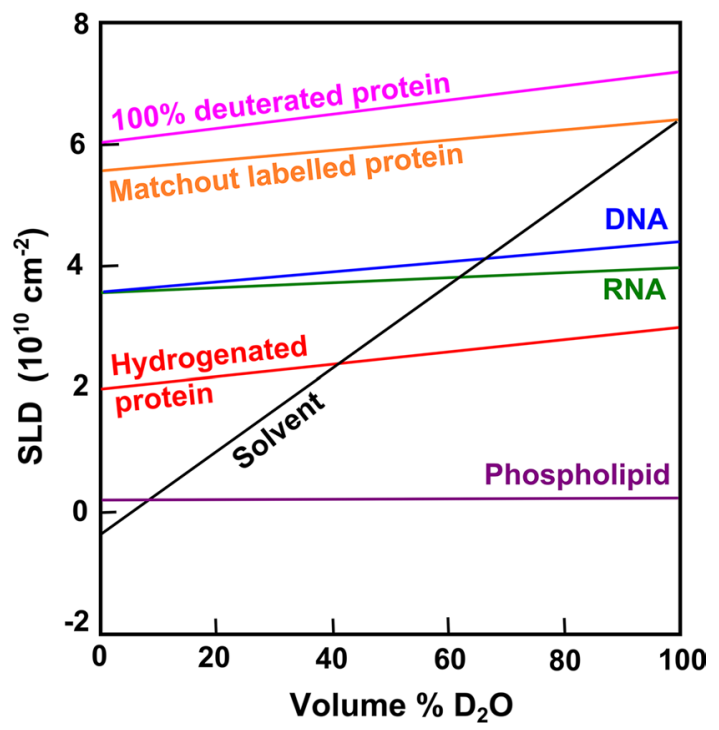

Fig. 1 The scattering length densities (SLDs) of the four major biomolecules are depicted as a function of the volume percentage of $\mathrm{D}_{2} \mathrm{O}$, assuming all labile hydrogen atoms are exchanged. The black line represents the variation of the solvent SLD. The match point of each biomolecule corresponds to the intersection of the solvent SLD with that for each biomolecule. Perdeuterated protein, in which all the hydrogen atoms are replaced by deuterium, has an SLD that is higher than that of $\mathrm{D}_{2} \mathrm{O}$ and cannot be solvent matched.
2012; Cuypers et al. 2013; Compton et al. 2014; Appolaire et al. 2014).

To distinguish between biomolecules having the same SLD, such as protein-protein complexes, deuterium labelling is necessary. Perdeuterated protein, where all the hydrogen atoms are replaced by deuterium, has an SLD higher than that of $\mathrm{D}_{2} \mathrm{O}$ (Fig. 1, magenta line) and cannot be fully solvent matched in SANS experiments. However, protein that is part-deuterium labelled such that its SLD is the same as that of $100 \% \mathrm{D}_{2} \mathrm{O}$ can be readily exploited in SANS studies. We refer to such sample material as being matchout labelled. This type of labelling is particularly advantageous in studies of protein-protein complexes in which one protein partner is hydrogenated and the other is matchout labelled. Here, as illustrated schematically in Fig. 2, SANS data would typically be recorded in three different buffers: (a) where the full complex is observable (e.g., $0 \% \mathrm{D}_{2} \mathrm{O}$ ), (b) where only the matchout labelled component is visible $\left(\sim 40 \% \mathrm{D}_{2} \mathrm{O}\right)$, (c) where only the hydrogenated component is visible $\left(100 \% \mathrm{D}_{2} \mathrm{O}\right)$. In (a), there should be good correspondence between SANS and SAXS analyses of the complex, although a lower radius of gyration may be expected for the SANS analysis of the matchout-labelled protein; this will occur because it will be measured in conditions where a high fraction of the surface solvent layer around the complex will be $\mathrm{H}_{2} \mathrm{O}$ which has a SLD close to zero (Svergun et al. 1998; Perkins 2001).

Methods to prepare appropriately deuterated proteins for SANS are required. The Escherichia coli and Pichia pastoris expression systems are both well characterised with numerous cell lines and expression plasmids available. The effect of $\mathrm{D}_{2} \mathrm{O}$ in $E$. coli growth media on the deuteration of RNA polymerase and ribosomal proteins has been studied in detail (Lederer et al. 1986; Leiting et al. 1998). A method

\section{A $0 \% \mathrm{D}_{2} \mathrm{O}$ buffer}

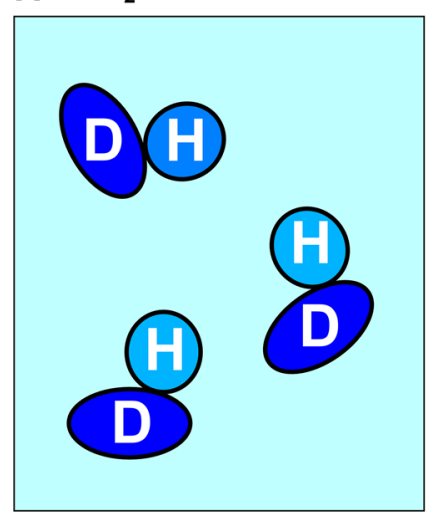

B $40 \% D_{2} \mathrm{O}$ buffer

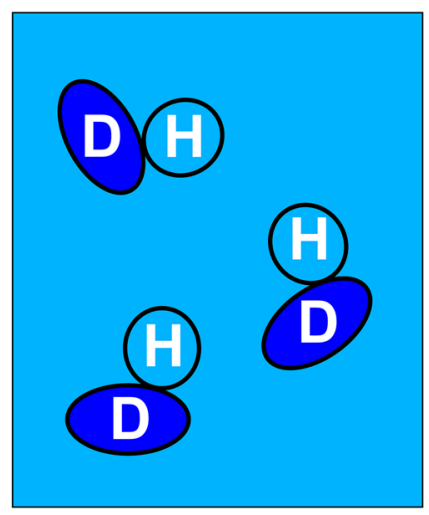

\section{C $100 \% \mathrm{D}_{2} \mathrm{O}$ buffer}

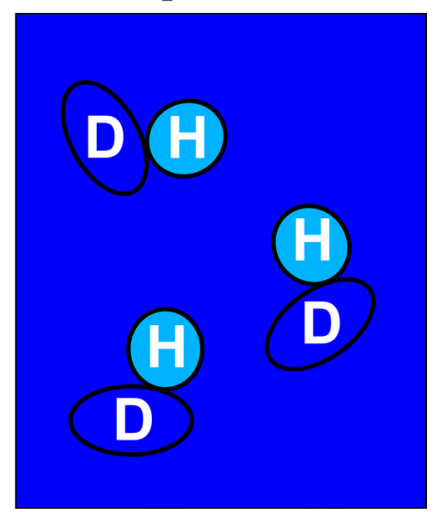

Fig. 2 Matchout regimes for a protein-protein complex in which one protein is matchout labelled ( $D$, dark blue) and the other is hydrogenated $(H$, medium blue). Following the scenarios summarised in the text, these correspond to a $0 \% \mathrm{D}_{2} \mathrm{O}$ in which both protein compo- nents are visible, $\mathbf{b} 40 \% \mathrm{D}_{2} \mathrm{O}$ where only the matchout labelled component $(D)$ is visible, and c $100 \% \mathrm{D}_{2} \mathrm{O}$ where only the hydrogenated component $(H)$ is visible 
to estimate deuteration levels in whole $E$. coli cells and cellular proteins by NMR has been described (Perkins 1981). For P. pastoris (yeast), fewer studies have been reported, although it is clear that this yeast can grow in deuterated media (Haon et al. 1993). Here, following development work in the Deuteration Laboratory (D-Lab) of the Life Sciences group at the Institut Laue-Langevin (Haertlein et al. 2016), we describe new deuteration techniques by which matchout labelled proteins can be routinely prepared using E. coli and P. pastoris. Both expression procedures utilise cell growth in minimal media based on $85 \% \mathrm{D}_{2} \mathrm{O}$ and a hydrogenated carbon source. The matchout labelled proteins were validated by mass spectrometry and SANS. In the case of the $E$. coli system, maltose binding protein (MBP) was used as a representative model system. MBP is a well-studied model protein that plays an important role in the metabolism of E. coli (Sharff et al. 1992) and is essential for the energy-dependent translocation of maltose and maltodextrins through the cytoplasmic membrane. For $P$. pastoris, a model system based on the C-terminal domain pair of human complement Factor $\mathrm{H}(\mathrm{CFH})$ was used. $\mathrm{CFH}$ is a key regulator of the complement system of innate immunity, in which its two C-terminal short complement regulator domains (SCR-19/20) are crucial for protecting host cells against undesired immune destruction (Rodriguez et al. 2014).

\section{Materials and methods}

\section{Protein production from $E$. coli in matchout conditions}

MBP was expressed using the E. coli BL21(DE3) cell line (Laux et al. 2008). High cell-density cultures were achieved using fermenters for cell growth. Minimal medium was prepared with the composition $6.86 \mathrm{~g} \mathrm{~L}^{-1}\left(\mathrm{NH}_{4}\right)_{2} \mathrm{SO}_{4}, 1.56 \mathrm{~g} \mathrm{~L}^{-1} \mathrm{KH}_{2} \mathrm{PO}_{4}, 6.48 \mathrm{~g} \mathrm{~L}^{-1}$ $\mathrm{Na}_{2} \mathrm{HPO}_{4} \cdot 2 \mathrm{H}_{2} \mathrm{O}, 0.49 \mathrm{~g} \mathrm{~L}^{-1}$ diammonium hydrogen citrate, $0.25 \mathrm{~g} \mathrm{~L}^{-1} \mathrm{MgSO}_{4} \cdot 7 \mathrm{H}_{2} \mathrm{O}, 1.0 \mathrm{~mL} \mathrm{~L}^{-1}\left(0.5 \mathrm{~g} \mathrm{~L}^{-1}\right.$ $\mathrm{CaCl}_{2} \cdot 2 \mathrm{H}_{2} \mathrm{O}, \quad 16.7 \mathrm{~g} \mathrm{~L}^{-1} \quad \mathrm{FeCl}_{3} \cdot 6 \mathrm{H}_{2} \mathrm{O}, 0.18 \mathrm{~g} \mathrm{~L}^{-1}$ $\mathrm{ZnSO}_{4} \cdot 7 \mathrm{H}_{2} \mathrm{O}, 0.16 \mathrm{~g} \mathrm{~L}^{-1} \mathrm{CuSO}_{4} \cdot 5 \mathrm{H}_{2} \mathrm{O}, 0.15 \mathrm{~g} \mathrm{~L}^{-1}$ $\mathrm{MnSO}_{4} \cdot 4 \mathrm{H}_{2} \mathrm{O}, 0.18 \mathrm{~g} \mathrm{~L}^{-1} \mathrm{CoCl}_{2} \cdot 6 \mathrm{H}_{2} \mathrm{O}, 20.1 \mathrm{~g} \mathrm{~L}^{-1}$ EDTA), and $5 \mathrm{~g} \mathrm{~L}^{-1}$ glycerol. The medium was supplemented with $40 \mathrm{mg} \mathrm{L}^{-1}$ kanamycin to select for the recombinant plasmid. The BL21(DE3) cells containing the DNA construct were firstly adapted to growth in minimal media using a stepwise process in which cells were inoculated into minimal media, grown for $36 \mathrm{~h}$ and then transferred into fresh minimal media. This was repeated until a sufficient growth rate was obtained. For the preparation of deuterated minimal media, the mineral salts were dried out in a rotary evaporator (Heidolph) at $60{ }^{\circ} \mathrm{C}$, then dissolved in a mixture containing $85 \% \mathrm{D}_{2} \mathrm{O} / 15 \% \mathrm{H}_{2} \mathrm{O}$. Cells were then adapted to growth in deuterated media. When a sufficient growth rate was achieved, large scale expression was carried out. Then $1.5 \mathrm{~L}$ of deuterated medium was inoculated with $100 \mathrm{~mL}$ pre-culture of adapted cells in a $3 \mathrm{~L}$ fermenter (Labfors, Infors). During the batch and fed-batch phases, the $\mathrm{pH}$ was adjusted to 6.9 by addition of $\mathrm{NaOD}$, and the temperature was adjusted to $30^{\circ} \mathrm{C}$. The gas-flow rate of sterile filtered air was $0.5 \mathrm{~L} \mathrm{~min}^{-1}$. Stirring was adjusted to ensure a dissolved oxygen tension of $30 \%$. The fed-batch phase was initiated when the optical density at $600 \mathrm{~nm}$ reached 5.1. Glycerol was added to the culture to keep the growth rate stable during fermentation. When the $\mathrm{OD}_{600}$ reached 14.7, over-expression was induced by the addition of $1 \mathrm{mM}$ IPTG and incubation continued for $24 \mathrm{~h}$. Cells were then harvested and stored at $-80^{\circ} \mathrm{C}$.

\section{Protein production from $\boldsymbol{P}$. pastoris in matchout conditions}

SCR-19/20 was expressed in yeast $P$. pastoris using the $\mathrm{X}-33$ cell line. Cloning and expression of hydrogenated SCR-19/20 were described in detail elsewhere (Cheng et al. 2005). Cells, which had previously been transformed with the plasmid construct, were adapted to growth in a minimal media. Minimal media consisted of $13.4 \%$ yeast nitrogen base, $0.02 \%$ biotin, $1 \%$ glycerol and $100 \mathrm{mM}$ potassium phosphate, $\mathrm{pH}$ 6.0. Adaptation was carried out by a similar protocol to that of the E. coli system, with the cells grown for $48 \mathrm{~h}$ before transferral into fresh minimal media. When high-density cell growth was achieved, cells were then adapted to growth in $85 \%$ deuterated minimal media by the same process. Deuterated minimal media was prepared as for the hydrogenated media, but was dissolved in $85 \% \mathrm{D}_{2} \mathrm{O}$. Large scale expression was then carried out by sustaining cell growth for $72 \mathrm{~h}$ in deuterated minimal media containing glycerol. Cells were then harvested by centrifugation and re-suspended in deuterated minimal media with $0.5 \%$ methanol in place of glycerol to induce protein expression. Expression was sustained for $96 \mathrm{~h}$ by feeding with $0.5 \%$ methanol every $24 \mathrm{~h}$. All cell growth and expression was carried out using baffled flasks with shaking at $220 \mathrm{rpm}$ at $29{ }^{\circ} \mathrm{C}$. Final cell cultures were centrifuged to remove the cells from the supernatant containing the secreted protein.

\section{Protein purification}

MBP from E. coli was expressed in a soluble form. Cells were broken by sonication and the insoluble fraction removed by centrifugation. For both proteins, purification was carried out using hydrogenated buffers according to the same protocol used for the hydrogenated protein. In the case of the MBP purification immobilized metal ion affinity chromatography (IMAC) on TALON (Clontech) was 
used. The supernatant was loaded on a column filled with $10 \mathrm{~mL}$ of TALON beads. This column was washed with 20 column volumes of lysis buffer containing $5 \mathrm{mM}$ imidazole in $10 \mathrm{mM}$ Tris-HCl, $100 \mathrm{mM} \mathrm{NaCl}, \mathrm{pH}$ 7.5. MBP was then eluted with $100 \mathrm{mM}$ imidazole. Fractions were analysed by polyacrylamide gel electrophoresis (PAGE), pooled and dialysed against $10 \mathrm{mM}$ Tris- $\mathrm{HCl}, 100 \mathrm{mM} \mathrm{NaCl}$, $\mathrm{pH}$ 7.5. $300 \mathrm{mg}$ of MBP was obtained from $1 \mathrm{~L}$ of media. For the SCR-19/20 purification, cation exchange chromatography was used on an SP FF column (GE Healthcare). The supernatant was dialysed against $50 \mathrm{mM}$ Tris, $25 \mathrm{mM}$ $\mathrm{NaCl}, 1 \mathrm{mM}$ EDTA, pH 7.4 and loaded onto the column. The column was washed with five column volumes of the same buffer. Elution was achieved by applying a $\mathrm{NaCl}$ salt gradient from $25 \mathrm{mM} \mathrm{NaCl}$ to $1 \mathrm{M} \mathrm{NaCl}$. Fractions were analysed by PAGE and were pooled and dialysed against $10 \mathrm{mM}$ Hepes, $137 \mathrm{mM} \mathrm{NaCl}, \mathrm{pH}$ 7.4. Approximately $7 \mathrm{mg}$ of SCR-19/20 was obtained from $1 \mathrm{~L}$ of start media. Further details for the MBP and SCR-19/20 purifications are given in Laux et al. (2008) and Dunne (2015) respectively.

\section{Mass spectrometry}

Matrix-assisted laser desorption/ionization-time of flight (MALDI-TOF) mass spectroscopy was carried out on the deuterated MBP and SCR-19/20 proteins. The matrix consisted of sinapinic acid in acetonitrile/water- $0.1 \%$ TFA (50:50). For both proteins, measurements were carried out at a concentration of $0.5 \mathrm{mg} / \mathrm{mL}$ in hydrogenated buffers. This meant that the calculation of the deuteration levels for the two matchout labelled proteins made the assumption that all of the labile deuterium atoms were replaced by hydrogen.

\section{SANS data collection}

Data were collected on the SANS instruments D22 (MBP) and D33 (SCR-19/20) at the Institut Laue-Langevin, Grenoble, France (Dewhurst et al. 2016). To calculate the match point, samples were prepared in a range of $\mathrm{D}_{2} \mathrm{O}$ concentration in the appropriate buffer. SANS data from MBP were collected in $0,20,40,60,80 \% \mathrm{D}_{2} \mathrm{O}$ buffers; SANS data for SCR-19/20 were collected in 0, 25, 40, 75 and $100 \% \mathrm{D}_{2} \mathrm{O}$ buffers. Data reduction, buffer subtraction, and transmission calculations were carried out using the program GRASP. The curves were fitted using Guinier plots (Guinier and Fournet 1955) yielding the radius of gyration $R_{\mathrm{G}}$ and the scattering intensity at zero angle $I(0)$. From this the normalised scattering amplitude of the proteins at each $\mathrm{D}_{2} \mathrm{O}$ concentration was calculated using the following expression:

$$
\sqrt{\frac{I(0)}{T c l}}
$$

where $T$ is the sample transmission, $l$ is the cuvette path length $(\mathrm{cm})$ and $c$ is the concentration $(\mathrm{mg} / \mathrm{mL})$. This scattering amplitude was plotted as a function of $\mathrm{D}_{2} \mathrm{O}$ percentage and a linear fit carried out. The contrast match point was taken as the intersection of this plot on the abscissa.

\section{Results}

Escherichia coli and Pichia pastoris cultures were successfully adapted to growth in deuterated minimal media. For both organisms, five changes of media were sufficient for adaptation. High cell densities were achieved using $3 \mathrm{~L}$ fermenters in which the conditions for growth were tightly controlled. For the production of E. coli cells in high celldensity cultures, the growth conditions were controlled and monitored using IRIS software (http://www.infors-ht.com). The induction of expression commenced at an OD of about 15 . Both proteins were expressed in their soluble forms and successfully purified using a similar protocol to that used for the same hydrogenated counterparts.

\section{Maltose binding protein (MBP)}

SDS-PAGE results before and after purification showed that MBP of high purity was obtained after a single IMAC purification step (Fig. 3A). The mass of normal hydrogenated MBP was measured to be 42,360 Da by mass spectrometry, and is identical to the value predicted from the sequence taking account for methionine aminopeptidase processing (Laux et al. 2008). Mass spectrometry measurements of the partially deuterated analogue (Fig. 4a) showed an increase

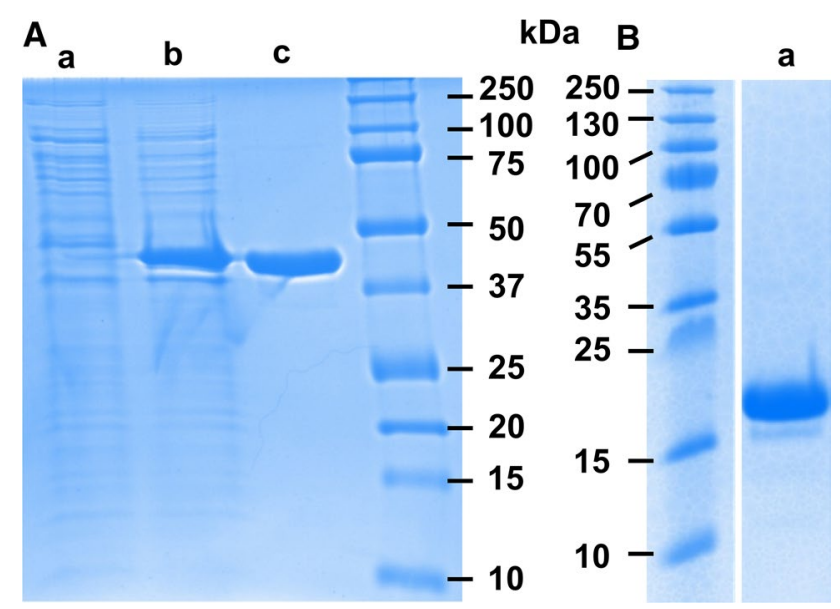

Fig. 3 SDS-PAGE results for the expression and purification of matchout labelled protein. A Maltose binding protein (MBP). $a$ Uninduced cellular extract; $b$ extract from induced cells; $c$ purified MBP after immobilized metal ion affinity chromatography. B SCR-19/20 from CFH. $a$ After cation exchange and size exclusion chromatography 


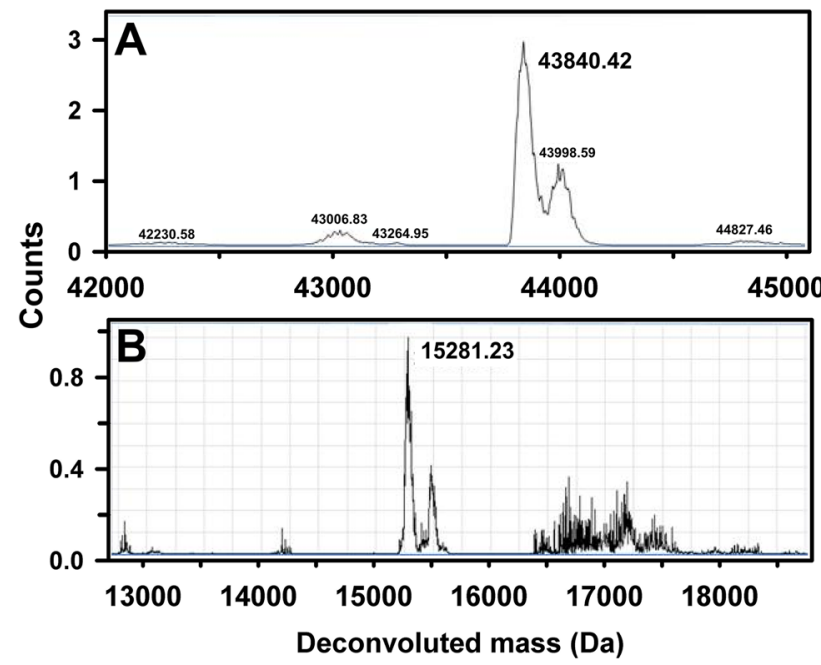

Fig. 4 Mass spectrometry measurement (MALDI-TOF) on the two matchout-labelled proteins. a For MBP, the single largest peak corresponds to a molecular weight of $43,840 \mathrm{Da}$, compared with 42,360 Da for the hydrogenated analogue. b For SCR-19/20, the central peak is associated with the properly processed SCR-19/20 protein $(15,281 \mathrm{Da})$

in mass to $43,840 \mathrm{Da}$ when measured in $\mathrm{H}_{2} \mathrm{O}$ buffer. The fully deuterated (aminopeptidase processed) $\mathrm{MBP}$ (in $\mathrm{D}_{2} \mathrm{O}$ solvent) was predicted to have a mass of 45,312 Da with the aid of the program ProtParam (Gasteiger et al. 2005); the deuteration level of the MBP was estimated to be $64.1 \%$ of the non-exchangeable hydrogen atoms. The smaller peak to the right of this in Fig. 4a is attributed to incomplete aminopeptidase processing of the matchout labelled MBP. The SANS data collected from MBP showed no evidence of aggregation at any contrast, and Guinier analyses were used to determine the $I(0)$ and $R_{\mathrm{G}}$ values for each contrast (Fig. $5 \mathrm{~A}$ ). The $R_{\mathrm{G}}$ value of MBP was $2.6 \mathrm{~nm}$. The variation of scattering amplitude $\sqrt{I(0)}$ as a function of solvent $\mathrm{D}_{2} \mathrm{O}$ composition for the partially deuterated MBP gave the contrast match point (Fig. 5B). That for the partially deuterated MBP expressed in a high cell-density culture with $85 \% \mathrm{D}_{2} \mathrm{O}$ as the only source of deuterium was determined to be $99.5 \% \mathrm{D}_{2} \mathrm{O}$.

\section{Complement factor H SCR-19/20}

Deuterated SCR-19/20 of high purity was obtained by cation exchange chromatography followed by size exclusion chromatography. This was confirmed by the PAGE results after purification (Fig. 3B). The yield of deuterated SCR-19/20 was calculated from the absorbance $($ A280 $\mathrm{nm}$ ) of the pooled size exclusion chromatography fractions corresponding to the protein peak. From $1 \mathrm{~L}$ of glycerol growth media, an average of $7.2 \mathrm{mg}$ protein was obtained. This yield was similar to the average of $7 \mathrm{mg}$ obtained for hydrogenated SCR-19/20 in hydrogenated nutrient rich media. The mass of hydrogenated SCR-19/20 was $14,734 \mathrm{Da}$. Mass spectrometry showed that the mass increased to 15,281 Da following deuteration (Fig. 4b). Because perdeuterated SCR-19/20 has an expected mass of $15,749 \mathrm{Da}$, the deuteration level was deduced to be $71.4 \%$ of the non-exchangeable hydrogen atoms. An additional peak was observed at $15,490 \mathrm{Da}$, corresponding to two additional amino acids, and was attributed to erroneous Kex protease processing of the signal peptide.

The SANS data for SCR-19/20 also showed no evidence of protein aggregation, and resulted in the $I(0)$ and $R_{\mathrm{G}}$ values for each contrast in Guinier plots (Fig. 5A). The $R_{\mathrm{G}}$ value was $2.2 \mathrm{~nm}$ for SCR-19/20. The scattering amplitude plot of $\sqrt{I(0)}$ for the partially deuterated SCR-19/20 gave a contrast match point of $97 \% \mathrm{D}_{2} \mathrm{O}$ and confirms that our protocol was optimal for the production of matchout labelled protein (Fig. 5B).

\section{Discussion and conclusion}

The novel deuteration methods described here allow the efficient production of matchout labelled proteins that are optimised for SANS structural studies in solution. For both proteins studied, the yields were similar to those observed for hydrogenated nutrient rich media. The difference in the deuteration levels (for the non-exchangeable hydrogen atoms) of the two proteins, as observed by mass spectrometry, are attributed to their different amino acid compositions and to differences in the growth media used. In both cases a 100 Da broadening of the main peak was observed by mass spectrometry, compared to the hydrogenated or perdeuterated proteins, and this reflects the nature of the random fractional deuteration regime used. For a typical SANS experiment, this labelling heterogeneity is not normally a problem. Proteins that are matchout labelled in this way are particularly useful in structural analyses of protein-protein complexes for which one protein of the pair would be labelled.

The advantages of this method of labelling are:

1. Matchout labelled proteins are very effective in SANS studies of complexes. Only a single preparation of complex containing a matchout labelled component is required to allow measurements for a complete SANS structural analysis. Measurements at $100 \%, \sim 40 \%$, and $0 \% \mathrm{D}_{2} \mathrm{O}$ solvent contrasts will yield structural information on the unlabelled component, the labelled component, and the full complex respectively, i.e., on conformational changes in either protein after complex formation, as well as the relative orientation of the two proteins in the complex. Such a study requires that the 
Fig. 5 A a Scattering curves for matchout-labelled MBP in buffers containing $0 \% \mathrm{D}_{2} \mathrm{O}$ (black), $20 \% \mathrm{D}_{2} \mathrm{O}$ (red), $40 \%$ $\mathrm{D}_{2} \mathrm{O}$ (blue), $60 \% \mathrm{D}_{2} \mathrm{O}$ (green) and $80 \% \mathrm{D}_{2} \mathrm{O}$ (pink). $b$ The corresponding Guinier plots for matchout-labelled MBP, with the coloured points representing the region of the scattering curve used to determine each $R_{\mathrm{G}}$ value. $c$ Scattering curves for matchout-labelled SCR$19 / 20$ in buffers containing $0 \%$ $\mathrm{D}_{2} \mathrm{O}$ (black), 25\% $\mathrm{D}_{2} \mathrm{O}$ (red), $40 \% \mathrm{D}_{2} \mathrm{O}$ (blue), and $75 \% \mathrm{D}_{2} \mathrm{O}$ (green). $d$ The corresponding Guinier plots for matchoutlabelled SCR-19/20, with the coloured points representing the region of the scattering curve used to determine each $R_{\mathrm{G}}$ value. B $a$ The analysis of $\sqrt{I(0)}$ as a function of the percentage $\mathrm{D}_{2} \mathrm{O}$ content in the buffer for matchout-labelled MBP expressed in E. coli. The matchpoint was $99.5 \% \mathrm{D}_{2} \mathrm{O}$. $b$ The analysis of $\sqrt{I(0)}$ for matchout-labelled SCR-19/20 expressed in $P$. pastoris as a function of the percentage $\mathrm{D}_{2} \mathrm{O}$ content in the buffer. The matchpoint was $97 \% \mathrm{D}_{2} \mathrm{O}$
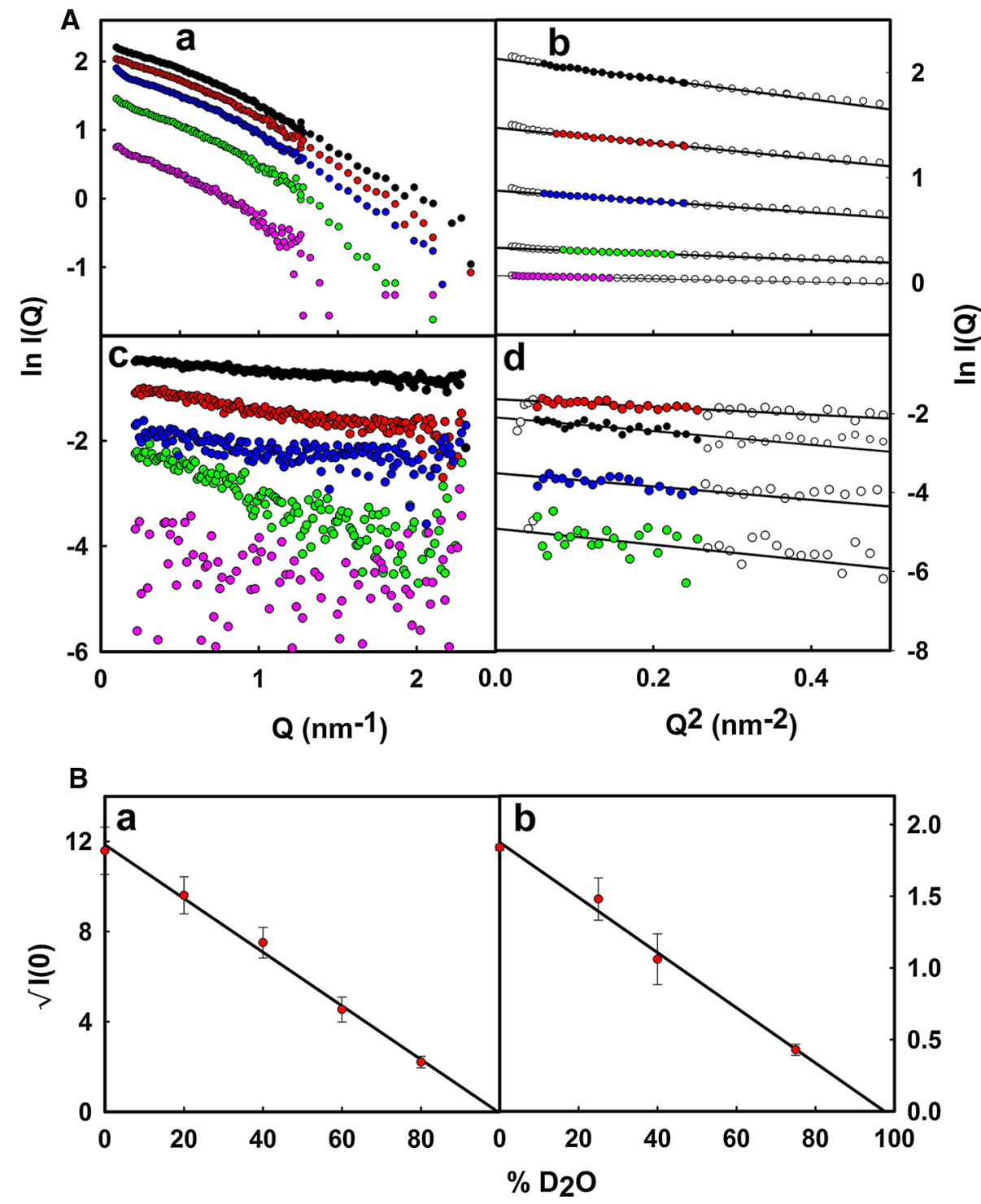

complex is stable (i.e., a low dissociation constant) and that there is no propensity for aggregation in all the required solvents. The approach has significant advantages over SANS experiments in which two separately labelled complexes are produced in which one of the two components is typically perdeuterated, and has already been successfully applied to numerous protein complexes.

2. The adaptation of host cells to growth conditions containing a hydrogenated carbon source and $85 \% \mathrm{D}_{2} \mathrm{O}$ is much more efficient than the culture conditions needed for perdeuteration.

3. Significant cost advantages are accrued, because no deuterated carbon source is needed in the culture medium. Since the solvent used is $\sim 85 \% \mathrm{D}_{2} \mathrm{O}$, this permits the effective use of recycled $\mathrm{D}_{2} \mathrm{O}$. Previouslydescribed methods used more expensive deuterated glycerol and deuterated methanol to obtain similar yields of protein (Massou et al. 1999; Pickford and O’Leary 2004).

The ability to label proteins using either E. coli or $P$. pastoris expression systems offers versatility in the labelling of recombinant proteins. For those systems where there are difficulties in expressing folded protein in E. coli, the use of $P$. pastoris offers a robust alternative in which issues associated with co-translational and post-translational modification are addressed. Future work of this type will focus on the development of similar matchout labelling approaches for insect cells and mammalian cells.

Acknowledgements The UK Engineering and Physical Sciences Research Council (EPSRC) is thanked for support under Grants EP/ C015452/1 and GR/R99393/01 that allowed the creation of the Deuteration Laboratory at the Institut Laue-Langevin, and also for Grant 
GR/R47950/01 that allowed associated diffractometer developments at the Institut Laue-Langevin. We also thank the Institut Laue-Langevin for beamtime on instruments D22 and D33. We thank University College London and the Institut Laue-Langevin for joint funding of studentship support to OD. The European Union is thanked for its support of methodological developments that occurred under contracts RII3-CT-2003505925 and NMP4-CT-2006-033256. This work used the platforms of the Grenoble Instruct centre (ISBG; UMS 3518 CNRS-CEA-UJF-EMBL) with support from FRISBI (ANR10-INSB-05-02) and GRAL (ANR-10-LABX-49-01) within the Grenoble Partnership for Structural Biology (PSB). We thank Luca Signor for assistance and access to the Mass Spectrometry facility. We also acknowledge Joe Zaccai for advice and for numerous helpful discussions.

\section{Compliance with ethical standards}

Conflict of interest The authors declare that they have no conflict of interest.

Open Access This article is distributed under the terms of the Creative Commons Attribution 4.0 International License (http://creativecommons.org/licenses/by/4.0/), which permits unrestricted use, distribution, and reproduction in any medium, provided you give appropriate credit to the original author(s) and the source, provide a link to the Creative Commons license, and indicate if changes were made.

\section{References}

Appolaire A, Girard E, Colombo M, Durá MA, Moulin M, Härtlein M, Franzetti B, Gabel F (2014) Small-angle neutron scattering reveals the assembly mode and oligomeric architecture of TET, a large, dodecameric aminopeptidase. Acta Crystallogr D 70:2983-2993

Callow P, Sukhodub A, Taylor J, Kneale G (2007) Shape and subunit organisation of the DNA methyltransferase M. Ahdl. J Mol Biol 69:177-185

Cheng Z, Jokiranta TS, Seeberger H, Jòzsi M, Heinen S, Noris M, Remuzzi G, Ormsby R, Gordon D, Meri S, Hellwage J, Zipfel PF (2005) Binding of complement factor $\mathrm{H}$ to endothelial cells is mediated by the carboxy-terminal glycosaminoglycan binding site. Am J Pathol 167:1173-1181

Compton EL, Page K, Findlay HE, Haertlein M, Moulin M, Zachariae U, Norman DG, Gabel F, Javelle A (2014) Conserved structure and domain organization among bacterial Slc26 transporters. Biochem J 463:297-307

Cuypers MG, Trubitsyna M, Callow P, Forsyth VT, Richardson JM (2013) Solution conformations of early intermediates in Mos1 transposition. Nucl Acids Res 41:2020-2033

Dewhurst CD, Grillo I, Honecker D, Bonnaud M, Jacques M, Amrouni C, Perillo-Marcone A, Manzin G, Cubitt R (2016) The small-angle neutron scattering instrument D33 at the Institut Laue-Langevin. J Appl Crystallogr 49:1-14

Dunne O (2015) Functional interactions of the C-terminus of the complement regulator Factor $\mathrm{H}$ with its ligands. $\mathrm{PhD}$ Thesis, University College London

Gasteiger E, Hoogland C, Gattiker A, Duvaud S, Wilkins MR, Appel RD, Bairoch A (2005) Protein identification and analysis tools on the ExPASy server. In: Walker JM (ed) The proteomics protocols handbook. Humana Press, New York, pp 571-607

Glatter O, Kratky O (1982) Small-angle X-ray scattering. Academic Press, London
Guinier A, Fournet G (1955) Small angle scattering of X-rays. Wiley, New York

Haertlein M, Moulin M, Devos J, Laux V, Dunne O, Forsyth VT (2016) Biomolecular deuteration for neutron structural biology and dynamics, methods in enzymology, vol. 566, Chapter 5, pp $113-157$

Haon S, Auge S, Tropis M, Milon A, Lindley NC (1993) Low cost production of perdeuterated biomass using methylotrophic yeasts. J Label Compd Radiopharm 33:1053-1063

Jacrot B (1976) The study of biological structure by neutron scattering from solution. Rep Prog Biophys 39:911-953

Laux V, Callow P, Svergun DI, Timmins PA, Forsyth VT, Haertlein M (2008) Selective deuteration of tryptophan and methionine residues in maltose binding protein: a model system for neutron scattering. Eur Biophys J 37:815-822

Lederer H, May RP, Kjems JK, Schaefer W, Crespi HL, Heumann H (1986) Deuterium incorporation into Escherichia coli proteins. A neutron-scattering study of DNA-dependent RNA polymerase. Eur J Biochem 156:655-659

Leiting B, Marsilio F, O'Connell JF (1998) Predictable deuteration of recombinant proteins expressed in Escherichia coli. Anal Biochem 265:351-355

Massou S, Puech V, Talmont F, Demange P, Lindley ND, Tropis M, Milon A (1999) Heterologous expression of a deuterated membrane-integrated receptor and partial deuteration in methylotrophic yeasts. J Biomol NMR 14:231-239

Niemann HH, Petoukhov MV, Härtlein M, Moulin M, Gherardi E, Timmins P, Heinz DW, Svergun DI (2008) X-ray and neutron small-angle scattering analysis of the complex formed by the Met receptor and the Listeria monocytogenes invasion protein InlB. J Mol Biol 377:489-500

Obarska-Kosinska A, Taylor JE, Callow P, Orlowski J, Bujnicki JM, Kneale G (2008) HsdR subunit of the type I restriction-modification enzyme EcoR124I: biophysical characterisation and structural modelling. J Mol Biol 376:438-452

Perkins SJ (1981) Estimation of deuteration levels in whole cells and cellular proteins by ${ }^{1} \mathrm{H}$ NMR spectroscopy and neutron scattering. Biochem J 199:163-170

Perkins SJ (2001) X-ray and neutron scattering analyses of hydration shells: a molecular interpretation based on sequence predictions and modelling fits. Biophys Chem 93:129-139

Pickford AR, O'Leary JM (2004) Isotopic labelling of recombinant proteins from the methylotrophic yeast Pichia pastoris. Methods Mol Biol 278:17-33

Rochel N, Ciesielski F, Godet J, Moman E, Roessle M, Peluso-Iltis C, Moulin M, Haertlein M, Callow P, Mély Y, Svergun DI, Moras D (2011) Common architecture of nuclear receptor heterodimers on DNA direct repeat elements with different spacings. Nat Struct Mol Biol 18:564-570

Rodriguez E, Rallapalli PM, Osborne AJ, Perkins SJ (2014) New functional and structural insights from updated mutational databases for complement factor $\mathrm{H}$, factor I, membrane cofactor protein and C3. Biosci Rep 34:e00146

Serdyuk IN, Zaccai NR, Zaccai J (2007) Methods in molecular biophysics. Cambridge University Press, Cambridge

Sharff AJ, Rodseth LE, Spurlino JC, Quiocho FA (1992) Crystallographic evidence of a large ligand-induced hinge-twist motion between the two domains of the maltodextrin binding protein involved in active transport and chemotaxis. Biochemistry $31: 10657-10663$

Shull CG (1962) International tables for X-ray crystallography. III:197-229

Stuhrmann HB (1974) Neutron small-angle scattering of biological macromolecules in solution. J Appl Crystallogr 7:173-178

Svergun DI, Richard S, Koch MH, Sayers Z, Kuprin S, Zaccai G (1998) Protein hydration in solution: experimental observation 
by X-ray and neutron scattering. Proc Natl Acad Sci USA 95:2267-2272

Svergun DI, Koch MHJ, Timmins PA, May RP (2013) Small angle $\mathrm{X}$-ray and neutron scattering from solutions of biological macromolecules. Oxford University Press, Oxford

Taylor JE, Swiderska A, Artero JB, Callow P, Kneale G (2012) Structural and functional analysis of the symmetrical Type I restriction endonuclease R.EcoR124I(NT). PLoS One 7:e35263
Vijayakrishnan S, Callow P, Nutley MA, McGow D, Gilbert D, Kropholler P, Cooper A, Byron O, Lindsay JG (2011) Variation in the organization and subunit composition of the mammalian pyruvate dehydrogenase complex E2/E3BP core assembly. Biochem J 437:565-574 